\title{
Roles of vitamin A and macula flava in maintaining vocal folds( Abstract_要旨)
}

\author{
$\operatorname{AUTHOR}(\mathrm{S})$ : \\ Tateya, Tomoko
}

CITATION:

Tateya, Tomoko. Roles of vitamin A and macula flava in maintaining vocal folds. 京都大学, 2008, 博士(医学)

ISSUE DATE:

2008-03-24

URL:

http://hdl.handle.net/2433/135815

RIGHT: 
氏 名楯谷智子

学位 (専攻分野) 博士 (医学)

学位記番号医 博 第 3195 号

学位授与の日付平成 20 年 3 月 24 日

学位授与の要件 学 位 規 則第 4 条第 1 項 該 当

研究科. 専攻医学研究科外科系専攻

学位論文題目 Roles of Vitamin A and Macula Flava in Maintaining Vocal Folds

(声帯の維持におけるビタミン A と声帯黄斑の役割についての研究)

論文調查委員教主授查) 別所和久教授鈴木茂彦教授三嶋理晃

\section{論文内容の要旨}

音声はヒトが社会生活を送る上で不可欠であるが、この音声は声帯が振動することでその源が作られる。声帯の粘膜固有 層は細胞外マトリックスが層状に存在し、声帯振動に適したユニークな構造をしている。声帯瘢痕は炎症・外傷等様々な原 因により起こり、声帯の瘏痕化により細胞外マトリックス構造が破壊され著しい嗄声をきたし生活の質は大きく損なわれる。 しかしながら声帯疟痕に対する有効な治療法は未だ見つかっていない。このような瘢痕形成の予防、治療には、声帯組織、 特に声帯の細胞外マトリックスの維持とその瘢痕化に関する基礎的な理解が不可欠である。

声帯黄斑は声帯の前端と後端にある組織であり、広い細胞質を持った細胞が蜜に集まっている場所である。この黄斑の機能 に関しては未だ不明であるが、仮説としては二説あり、一つはヒトでは声帯䩲帯が黄斑に繋がっている事から、これが声帯 振動を行う弦の端として働いているというあのである。あう一つはこの黄斑が声帯の粘膜固有層に対して細胞外マトリック スの供給源となっているというあのである。

黄斑が細胞外マトリックスを産生しているとされる根拠は、声帯星型細胞の存在である。この細胞は七ト声帯においては 黄斑に特異的に存在し、豊富な細胞質と多くの細胞突起を持ち、細胞質内の油滴にビタミン A を貯蔵していることが知られ ている。この細胞にコラーゲンやエラスチンの線維が貯留していることが電顕で確認されることから、声帯星型細胞が声帯 粘膜固有層を構成する細胞外マトリックスの生成に関与しているのではと推察されている。しかしながら、ビタミン Aの声 帯星型細胞や声帯粘膜固有層における役割は未だ不明であった。

ビタミン A 貯蔵声帯星型細胞は、ヒトのみならず、ラット声帯の黄斑にも存在していることが確認されている。そこでラ ットをモデル動物として、ビタミン A の声帯星型細胞や声帯粘膜固有層への影響を調べるため、後天性ビタミン $\mathrm{A}$ 欠乏ラッ トを作製した。

コントロール群とビタミン $\mathrm{A}$ 欠そラット群の星型細胞を比較すると、コントロールでは細胞質内にビタミン $\mathrm{A}$ 貯蓄油滴が 豊富に認められたが、ビタミン $\mathrm{A}$ 欠乏ラットではほとんど見られず、ビタミン A が枯渇していることが示唆された。ビメン チンの免疫染色では、コントロールでは豊富な細胞質を持っているのに対し、ビタミン $\mathrm{A}$ 欠乏ラットでは細胞質が著明に減 少し、N/C 比は有意に増加していた。

これらの星状細胞でのビタミン $\mathrm{A}$ の枯渇が粘膜固有層の細胞外マトリックスに影響を与えているのかどうかを調べた。ビ タミン $\mathrm{A}$ 欠乏ラットでは声帯上皮の著明な肥厚を認めたが、ヒアルロン酸抢よびェラスチンの分布には差を認めなかった。 コラーゲンの I 型と III 型の分布およびコラーゲン線維の走行む、明らかな差を認めなかった。

さらに声帯黄斑での細胞外マトリックス生成能をリアルタイム PCR で調べた。プロコラーゲン I 型の m RNA のみビタミン $\mathrm{A}$ 欠乏ラットで有意に発現が減少していたが、プロコラーゲン III 型、ヒアルロン酸合成酵素 1 、 2 型、エラスチンの $\mathrm{m} R \mathrm{~N}$ A 発現は有意な差を認めなかった。

以上より、ビタミン A欠乏ラットにおいて黄班部で星状細胞の核/細胞質比が有意に増加していたものの、声帯粘膜固有層 
の細胞外マトリックスではほとんど变化を認めなかった。少なくとも成体の声帯ではビタミン A は粘膜固有層の細胞外マト リックスの維持に重要な役割を果たしていないことが示唆された。

\section{論 文 審 査 の 結 果 の 要 旨}

声帯の粘膜固有層は細胞外マトリックスが層状に存在し、声帯振動に適したユニークな構造をしている。声帯粘膜の粘弾 性の維持にはこれら細胞外マトリックスの恒常的代謝が必要不可欠と考えられているが、そのメカニズムについては十分に は解明されていない。特に声帯の組織損傷後の再生機構を知るためには、細胞外マトリックスの内因的な維持機構を理解す る必要がある。

細胞外マトリックスの供給源として声帯前後端の黄斑にあるビタミン A 貯蔵星型細胞が有力視されているが、その機能や ビタミン A の役割は不明な点が多い。本研究では、後天性ビタミンA欠乏ラットを作製し、ビタミン Aの声帯細胞外マトリ ックス代謝に及ぼす影響を調べた。

結果、ビタミン A 欠乏ラットでは声帯星型細胞のビタミン A 枯渇を認めたが、声帯粘膜固有層の主要な細胞外マトリック スの分布には異常を認めなかった。また声帯黄斑での細胞外マトリックス生成能を見るために声帯粘膜固有層の主要な細胞 外マトリックスの mRNA を調ベたが、コントロール群と比べて有意差を認めなかった。

以上より、ラット成体では声帯星型細胞のビタミン A 枯渇が声帯粘膜固有層の細胞外マトリックスに著明な影響を与えない ことが示唆された。

本研究は、声帯星型細胞の機能解明に貢献し、声帯粘膜の恒常性維持に関する基礎的理解に寄与するあのである。

したがって、本論文は博士 (医学) の学位論文として価值あるあのと認める。なお、本学位論文は平成 20 年 1 月 22 日実 施の論文内容とそれに関連した試問を受け合格と認められたあのである。 